\title{
まれな形態をした甲状舌管囊胞症例
}

$\begin{array}{lrl}\text { 兵 } & \text { 行彦・稲福 } & \text { 繁・石神 } \\ \text { 寛通 } \\ \text { 瀧本 } & \text { 勲. 岩崎 } & \text { 博* }\end{array}$

\section{A Rare Thyroglossal Duct Cyst}

\author{
Yukihiko Hyo, Shigeru Inafuku, Hiromichi Ishigami and Isao Takimoto \\ (Aichi Medical University) \\ Hiroshi Iwasaki \\ (Toki General Hospital)
}

A rare thyroglossal duct cyst in a 22-year-old male is reported. There were two cysts, one at the back of the right submandibular gland and the other above the right lobe of thyroid, which were connected through a single duct. The two cysts and duct were surgically resected. Histological examination showed a thyroglossal duct cyst.

Key words: thyroglossal duct cyst, branchial cleft cyst, congenital cervical cyst

\section{はじめに}

非定型的な頸部の腫瘤性疾患に遭遇した場合 には診断，治療に苦慮することがある．今回我

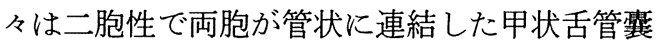
胞の一例を経験したので報告する.

症例

患者 : 22歳, 男性

主訴 : 右頸部腫脹.

既往歴 : 小児期に右甲状腺上部の腫脹と排膿 を繰り返した。

家庭歴：母が弁膜症で手術.

現病歴： 1 年半前より右顎下部の腫脹があり, 他院で手術をすすめられた. 平成 2 年 2 月, 当 大学分院耳鼻咽喉科を受診した.

現症: 右顎下腺後方と甲状腺右葉直上にそれ ぞれ $1.5 \times 4.0 \mathrm{~cm}, 1.0 \times 2.5 \mathrm{~cm}$ 大の弾性軟の
腫瘤を触れた。境界明瞭で圧痛, 発赤はなかっ た。 下方の腫瘤の皮膚面には瘻孔跡とみられる 針頭大の小孔があったが排液はなかった。

諸検査結果：血液検査, 臨床化学検査はほぼ 正常所見であった。他院撮影の CT（図1)では 顎下部は $2.0 \times 2.0 \mathrm{~cm}$ 大の境界明瞭, 充実性 腫瘤陰影の所見で, 一方ェュー（図 2 )では製胞 性の画像を呈していた。

経過 : 病歴, エュー所見より先天性䛚胞性疾 患が考えられたため, 平成 2 年 3 月 12 日全身麻 酔下に摘出術を行った.

手術所見：術前の右頸部の写真(図 3 )で, 左 が頭側で，左の黒丸印が顎下部，右が甲状腺部 である．顎下部の腫瘤上に正中付近まで切開を し，広頸笳を剥離すると右顎下，顎二腹筋腱上， 右顎下腺後方に淡紅色の囊胞があり, これは胸 
鎖乳突筋前方, 内頸動脈直上に位置していた。 さらに正中付近の切開端から甲状腺部の腫瘤上 へ切開を加党ると，下方へ子管状に連なり甲状 腺右葉直上で霊胞を形成していた。同上皮膚に 瘦孔が開口して拉り，一塊として摘出したが，

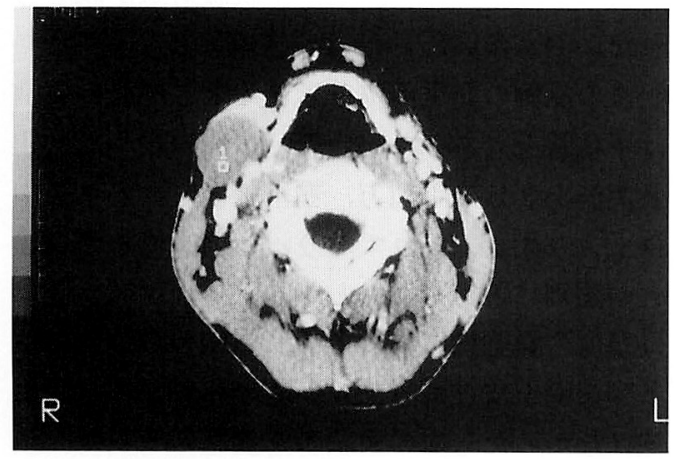

図 1

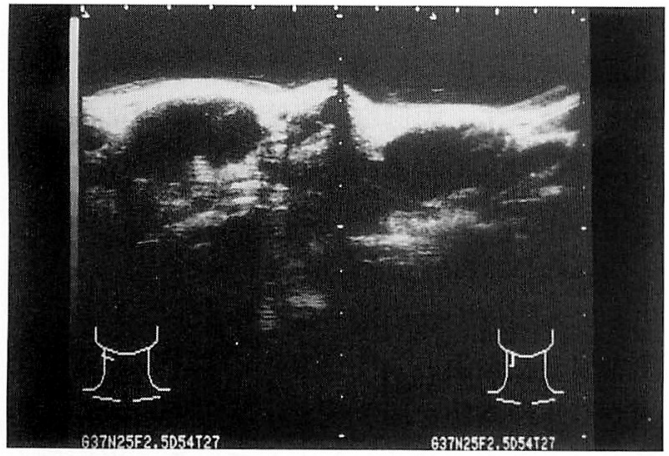

図 2

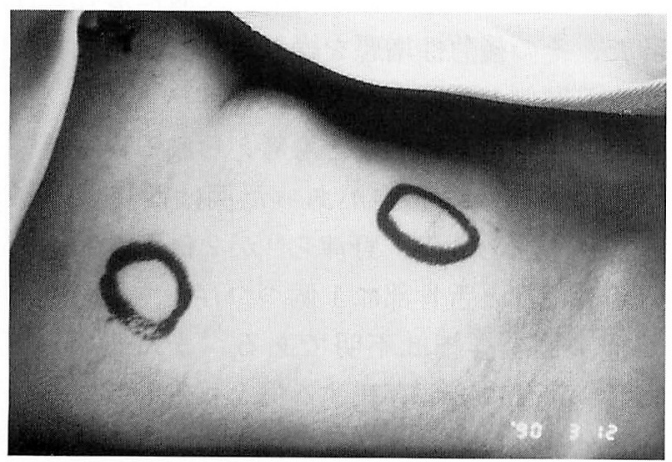

図 3
上部の囊胞から下咽頭への開口，連絡は確認で きなかった。周囲との癒着は少なく剥離摘出は 容易であった。

肉眼的所見 : 囊胞部を切開した摘出物の写真 (図 4 ) で左方が頭側である. 全長 $11.5 \mathrm{~cm}$ で, 切開すると頭側囊胞には茶褐色，尾側霊胞には 黄緑色の粘液が眝留していた。

病理組織検査: 頭側の囊胞内には移行上皮が みられた(図 5 )。管状の部分は管の周囲に横紋 筋組織, 膠原組織, 脂肪組織があった(図 6 ). 尾側の囊胞内には多列線毛上皮があり，一部に 扁平上皮, 皮膚付属器を認めた(図 7 )。 甲状腺 組織,リンパ組織はいずれの部位にもみられな かった。

術後経過：経過良好にて術後11日で退院し， その後平成 5 年 12 月まで再発を認めていない。

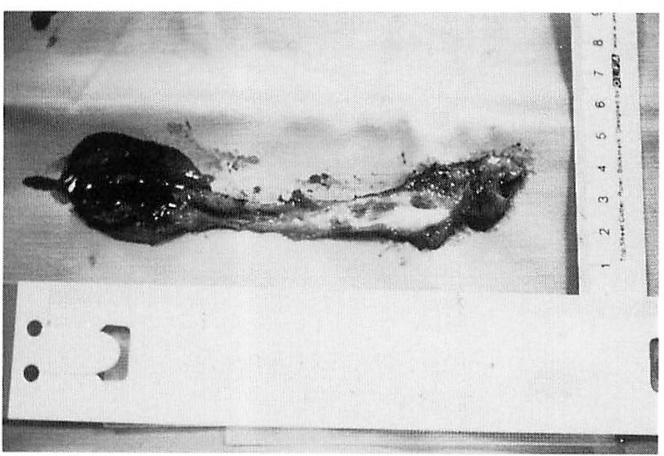

図 4

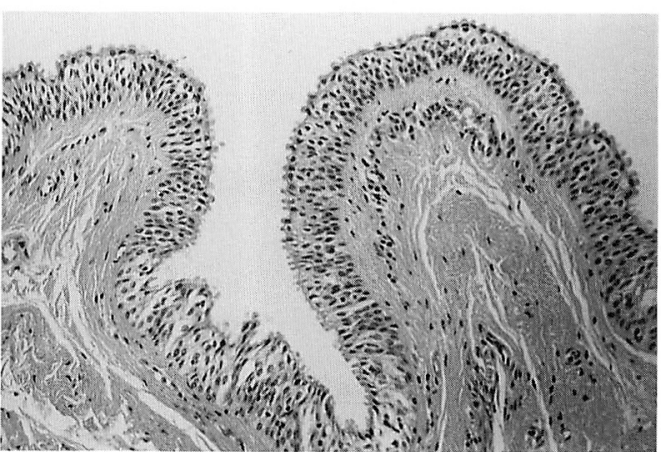

図 5 
考察

甲状舌管雯胞は甲状舌管の遺残組織より発生 するとされている。状腺原基は甲状舌管とな り，頸部正中を下降し甲状腺を形成する．甲状 舌管は胎生 6 週以後に形成される舌骨により上 下に二分され，上皮と管腔は消失するがこの消 失機転に異常が起こると囊胞形成の原因となり 感染を起こしたり，切開，穿刺を繰り返すと癭 孔となる。

発生部位は舌骨下部の正中線上に発生するこ

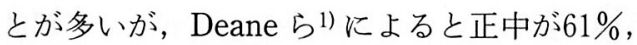
右側15\%, 左側 $24 \%$ としている. Biley2) は左, 右側よりの発生を甲状舌管の側枝からのものと 推定して拉り，また坂倉 ${ }^{3)}$ は上方は舌盲孔から 下方は胸骨上窩まで，正中線上に限定するとは 限らず，両側胸鎖乳突筋の前縁までの範囲に発 生しらるとしている。

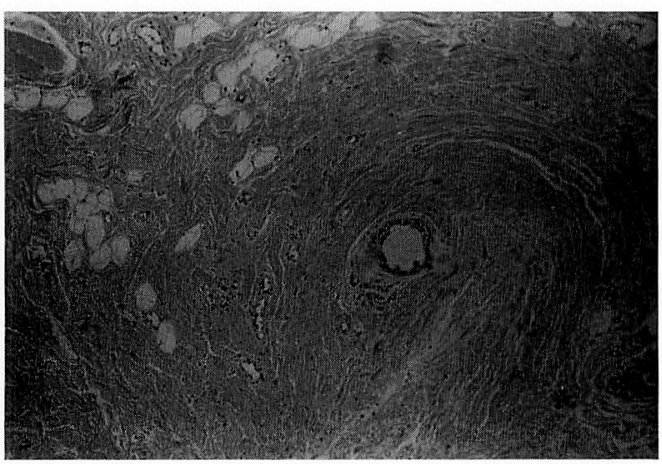

図 6

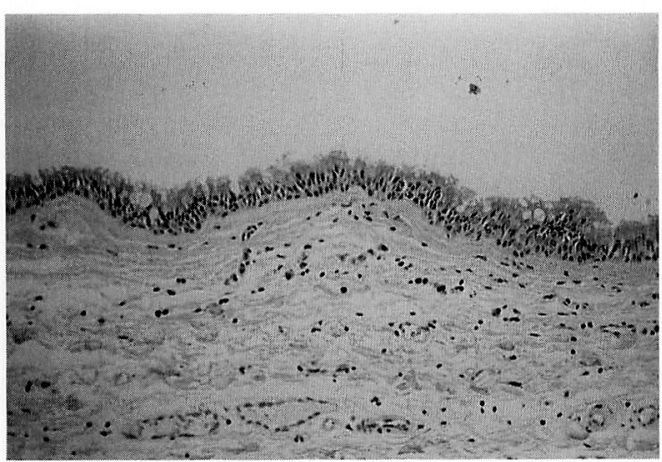

図 7
組織学的には甲状舌管囊胞や瘦孔の内壁は一 般に円柱上皮か線毛上皮であり，炎症をともな らことにより移行上皮から一層, 重層の扁平上 皮に化生するとされている4)5)。 また，同褧胞 での甲状腺組織の存在は北村ら ${ }^{6)}$ では25.9\%， 平野ら ${ }^{7)}$ は $36.4 \%$, 野津ら ${ }^{8)}$ は27\%認められた と報告している。しかし，甲状腺組織が認めら れない例も多い。

この症例の発生部位を考兵ると，尾側の囊胞 は甲状腺上にあったものの，頭側の囊胞は胸鎖 乳突筋上 3 分の 1 前方, 顎下腺後方にあり正中 線上より大さくずれて呿り, 術前は側頸囊胞等 との鑑別に苦慮した。しかし，病理組織検査で は頭側の囊胞内に移行上皮, 尾側の囊胞内には 多列線毛上皮と扁平上皮が認められ，甲状腺組 織はなかったものの甲状舌管囊胞の所見に一致 した。 また，側頸製胞に特徵的なリンパ組織， 皮様囊胞にあるケラチン様内容物や皮膚付属器 もみられずこれらは考えられなかった。ささらに 通常の発生部位から側方へずれているが，正中 線上に限らず，両側胸鎖乳突筋の前縁までの範 囲に発生しらること3) と組織学的所見から考兄 て甲状舌管囊胞と診断した。

西嶌ら ${ }^{9)}$ は舌骨を上下から挟むような形で発 生した二室性の正中頸褧腫を報告しており，2 室を呈した理由として初めに舌骨下に存在した 囊胞が急性増悪を繰り返し甲状舌管を介して舌 骨上にも炎症が波及したとしている，当症例も 現病歷から考光ると，西嶌ら ${ }^{9)}$ と同様に最初は 尾側の翼胞が感染を繰り返し，皮膚に㾇孔を作 った。その後急性増悪を繰り返して，甲状舌管 を介し頭側の豊胞へ波及したと推察される．当 症例の甲状舌管は側枝とも考兄られる。

その他複数の囊胞があった例は西嶌ら ${ }^{10)}$ が 上記例も含め 3 例, 野津ら ${ }^{8)}$ が 2 例でらち 1 例 は舌骨上部と舌骨部に 1 個づつ存在するものだ が他 1 例の詳細は不明である。また䗄川ら ${ }^{11)}$ は舌骨下部に 2 個存在する例を報告している. Allard ${ }^{12)}$ は収集した文献中舌骨の両側にある 1 例を記載している. 当科でも当症例の他に舌骨 
部と舌骨上部に 1 個づつ存在する 1 例があった. しかし渉弾し得た検索範囲内では二胞あって一 方の霊胞が側方へ偏位している例はなかった。

$$
\text { まとめ }
$$

(1)右顎下腺後方と甲状腺右葉直上に霓胞があ り両襄胞が管状に連結した甲状舌管霊胞の一例 を報告した。

(2)尾側の価胞が感染を繰り返し，甲状舌管を 介して頭側の囊胞へ波及したと推察した。

\section{文献}

1) Deane SA and Telander RL : Surgery for thyroglossal duct and branchial cleft anomalies. Am J Surg 136 : 348 353, 1978.

2) Bailey $\mathrm{H}:$ Thyroglossal cysts and fistulae. $\mathrm{Br}$ J Surg $12: 579 \sim 589,1925$.

3）坂倉康夫：先天性頸部腫瘤. 耳鼻咽喉科頭頸部 外科 MONK 2 顔面頸部腫瘤(斎藤等編) 112 121頁, 金原出版, 東京, 1986.

4）執行作蔵: 先天性頸部正中線瘦孔. 日耳鼻 24 : 181 206, 1919.

5）鶴田至宏：正中頸瘦. JOHNS $7: 765 \sim 768$, 1991.
6）北村龍彦，松山四郎，鈴木則夫, 他：甲状舌管 褧胞の検討. 日小外会誌 $21 ： 977 \sim 984,1985$.

7) 平野裕士, 篠原正徳, 川野芳春, 他: 甲状舌管 霊胞の臨床的・病理組織学的検索. 日口外誌 $34:$ 695 703, 1988.

8）野津 長, 広田 裕, 林 英一, 他：甲状舌管 褧胞・㾇25例の経験. 鳥取医誌 $14: 159 \sim 161$, 1986.

9) 西嶌 渡, 竹生田勝次, 寺邑公子, 他: 特殊な 形態を呈した正中頸襄腫の 1 症例. 耳喉 55 : 393 397, 1983.

10）西嶌 渡, 竹生田勝次, 野崎信行, 他: 19例の 甲状舌管慗胞. 耳喉頭頸 $60: 473 \sim 477,1988$.

11）蜙川郁子, 別所和久, 松木優典, 他: 甲状舌管 䏝胞の 2 症例について.日口外誌 $33: 381 \sim 385$, 1987.

12) Allard HB Remy: The thyroglossal cyst. Head Neck Surg 5 : 134 146, 1982.

$$
\left(\begin{array}{c}
\text { 別刷請求先 : 兵 行彦 } \\
\mathbf{T} 480-11 \text { 愛知県愛知郡長久手町 } \\
\text { 大字岩作字倠又 } 21 \\
\text { 愛知医科大学耳鼻咽嗼科学教室 }
\end{array}\right)
$$

